\title{
Effect of Cellular Tower Radiation towards Human Tissues at Bangladesh Context
}

\author{
Tapasy Rabeya, Mst. Eshita Khatun, Syed Akhter Hossain
}

\begin{abstract}
With the rapid technological advancement the increasing cell phone dependency has led to set up cellular towers in numerous communities. These towers are known as base stations, have antennas and electronic equipment that transmit and receive $R F$ (radio-frequency) signals. Various experimental and epidemiological analysis have been done for searching the potential effect of BTS (Base Transceiver Station) establishment in residential areas and result shows significant health issues, as the $R F$ radiation can mess with the human body's own EMFs. Therefore, for ensuring public safety it is essential to ascertain the minimum safe distance of establishing BTSs from locality. In this calculation based empirical work, on the basis of SAR (Specific Absorption Rate) mentioned by the World Health Organization, we have analyzed and proposed the minimum reasonable distance of nine major human tissues for being affected by the radiation. This analysis has been done at different frequency bands based on a specific type of antenna at Bangladesh context.
\end{abstract}

Keywords: Cell tower radiation, Radiation effect, Specific Absorption Rate, Base Transceiver Station, Antenna safety limit.

\section{INTRODUCTION}

In today's world, mobile phones have become a standard item and have an enormous contact with moment access to instant messages, emails, social platforms, games and for all intents and purposes everything else individuals could need. Cell phones and tablets have become the best specialized instruments, particularly in metropolitan urban areas. A statistics shows that, in a world of 7.4 billion the quantity of cell phone clients has gone up to 5 billion [1]. Thus, the fixation on cell phones is beginning to look like a habit. Individuals utilize their telephones when they're strolling, driving, spending time with companions, hanging out with friends, remaining in line, and even using the restroom. According to a U.S. examination report, 18 to 44 year olds who possess cell phones spend more than two hours daily

Revised Manuscript Received on February 05, 2020.

* Correspondence Author

Tapasy Rabeya*, Department of Computer Science and Engineering, Daffodil International University, Dhaka, Bangladesh. Email: tapasyrabeya.cse@diu.edu.bd

Mst. Eshita Khatun, Department of Computer Science and Engineering, Daffodil International University, Dhaka, Bangladesh. Email: eshita.cse@diu.edu.bd

Syed Akhter Hossain, Department of Computer Science and Engineering, Daffodil International University, Dhaka, Bangladesh. Email: aktarhossain@daffodilvarsity.edu.bd

(C) The Authors. Published by Blue Eyes Intelligence Engineering and Sciences Publication (BEIESP). This is an open access article under the CC BY-NC-ND license (http://creativecommons.org/licenses/by-nc-nd/4.0/) communicating with individuals by means of informing or social media on their cell phones [21]. To provide proper networking coverage, the utilization of mobile Phone has been quickly spread internationally. In any case, impacts of cell phone tower radiations are seen in Numerous nations and Bangladesh. Diverse Research shows the cell radiation's impact on human body. In ongoing year's different communication tools and cell phone towers has become universal and continuous for exposing the general public to radiofrequency (RF) fields [2]. In Bangladesh, the utilization of cell phones has expanded in the course of recent years with the complete number of cell phone dynamic supporters arriving at 120 million toward the end of December 2017[3]. Simultaneously a critical increment has been done, in the establishments of portable base stations, accompanied by public concern for possible environmental and health impacts related to exposure to electromagnetic waves spreading from towers. As recently the ratio of establishing cell phone tower in the residential area is increasing simultaneously and sometimes, coverage region of these waves incorporates human creatures very closely, particularly when the tower is arranged on the rooftop. In Bangladesh, the cell tower antenna is produced on the basis of three frequency range; such as $900 \mathrm{MHz}$, $1800 \mathrm{MHz}$ and $2100 \mathrm{MHz}$ for providing up to $4 \mathrm{G}$ services by different operators [22]. So, it is indeed needed to know how the radiation is affecting the different tissues of the human body. And what are the safety limits for important human tissue from the BST (Base transceiver Station). In this analytical research, we have focused on 9 major human tissues. As there are different Bangladeshi and foreign antenna manufacturing company is available, so we have explored on a specific antenna type and analyzed the SAR (Specific Absorption Rate) for 9 human tissues. And finally, we defined the safety limit for each of the chosen tissue from cell phone towers towards human health.

The following paper is arranged as follows. In the section I we have described the introduction. In the next section II, a summary of background study in this research field is presented as literature review. A small visualization of present condition of Bangladesh is presented in section III. The research methodology is stated in the IV section. The analysis and result are narrated in the section $\mathrm{V}$ and finally the conclusion is presented in section VI. The references are added in the last section. 


\section{Effect of Cellular Tower Radiation towards Human Tissues at Bangladesh Context}

\section{LITERETURE REVIEW}

Over the year's different genuine medical issues are causing for the persistent introduction to microwave radiation from TV, FM towers and Cell telephone towers as well as. Estimations have been done and it has been discovered that the levels of radiations are extremely high in different places close to the cell towers. As the body has certain defense mechanisms and the pressure is on the stress proteins of the body, namely the heat shock Proteins, but in any case of exposure the impacts have not seen in the initial years [18]. Since human body contains $70 \%$ of fluid, at the point when a human body is exposed to electromagnetic radiation, it absorbs radiation as like cooking in the microwave (oven). One factor is that the human height is so prominent than the wavelength. So, the frequency creates different resonance which makes confined warming inside the body by transmitting of the cordless telephone tower. This outcome in boils, evaporating the liquids around eyes, brain, joints, heart, stomach area, and so forth [17].

Kid's skulls are slenderer and they are more vulnerable to radio frequency radiation emanations as their sensory system is as yet creating and myelin sheath is yet not developed. An examination in Australia found that children had more than double leukemia rate who living close to TV and FM communicate towers [7]. In another examination, Immunoglobulin $\mathrm{G}$ and $\mathrm{A}$ have expanded also diminished lymphocytes and T8 cells, bringing about a lessening in immune reaction of the workers of TV signal [16]. The RF radiations consistently respond with the creating undeveloped organism and expanding cells, because of the fact a pregnant lady and the baby both are vulnerable.

DNA harm by means of free radical development inside cells has also been recorded [13]. Free radicals decimate cells by harming macromolecules, for example, protein, DNA and membrane are carcinogenic. Actually, EMR upgrades free radical action. DNA breaks in single and double strand are found in cells of rat brain after intense exposure to radio frequency of electromagnetic radiation [14].

Particularly after the fast introduction of versatile media communications frameworks, critical care has been increased about the possible health effects from exposure to radio frequency electromagnetic fields. Guardians are particularly worried about the probability that cancer can be developed in kid's body where the cell phone base stations raised closer to schools. An assessment was made in Israel, in Netanya, to decide if the outbreak of cancer cases among people presented to a wireless transmitter station is unique in relation to that normal, or when contrasted with individuals who lived in a close by zone. A survey was taken from two groups of people, where the first group was having 622 individuals and for 3-7 years, they were living near a base transceiver station. And additionally, they were patients in a health clinic. The second group was with 1222 individuals, and they received their medicinal treatment in a nearby clinic. Eight different types of cancer were diagnosed in the base station located area within only one year of exposure. For the first group of individuals the relative cancer rates for females 10.5 and 0.6 for second group of individuals and 1 for the whole town of Netanya. A correlation of the relative hazard uncovered that there were 4.15 times a greater number of cases in zone A than in the whole populace. The examination shows a relationship between expanded occurrence of cancer and living in vicinity to a mobile phone transmitter station [15].

Some neurodegenerative diseases are classified those causes for the death of explicit neurons, like as motor neuron disease, Alzheimer's sickness and Parkinson's infection [6]. There is a strong possibility of developing some neuropsychiatric problems, like memory loss, dizziness, muscle spasms, altered reflexes, headache, leg/foot pain, muscle and joint pain, nausea, numbness, sleep disturbance, tingling and depression who living near to cellular base station [8]. Another paper summaries the effect of radio-frequency from cell towers and cordless devices on the biosphere. And they conclude that some cells can be changed at very low intensities by the RF-EMF radiation, like cellular metabolism, calcium efflux, blood-brain barrier, electrophysiology, morphology, neurotransmitter functions, gene and protein expression [10].

There is a strong possibility of developing some neuropsychiatric problems, like memory loss, dizziness, muscle spasms, altered reflexes, headache, leg/foot pain, muscle and joint pain, nausea, numbness, sleep disturbance, tingling and depression who living near to cellular base station [8]. Another paper summaries the effect of radio-frequency from cell towers and cordless devices on the biosphere. And they conclude that some cells can be changed at very low intensities by the RF-EMF radiation, like cellular metabolism, calcium efflux, blood-brain barrier, electrophysiology, morphology, neurotransmitter functions, gene and protein expression [10].

It is almost clear that the Impacts of RF-EMF (radio-frequency electromagnetic fields) are truly affecting the bio system and ecosystem. Different experiments were committed in the recent years on plants, amphibians, reptiles, insects, mammals, birds and humans. Hence the result shows alarming condition. Centre for Environment and Vocational Studies of Punjab University have done an experiment on sparrows, and result shows that the fetus of around 50 eggs were damaged only for 5-30 minutes explosion of mobile tower radiation [11]. In Western Massachusetts (Doyon, 2008) a survey was taken on two similar habitats in two different berry farms. Where one firm was having no cell phone tower. And another was with the presence of cell phone tower. Result showed abundant signs of wildlife, resident birds, migrating and insects including bats, small and large mammals, bees etc. in the first firm. And there were no such significant living creatures sign in second farm [12].

An investigation was carried out on radio stations, TV stations, Grameenphone, Aktel, Banglalink and PBTL - City Cell (Pacific Bangladesh Telecom Limited) for calculating the effect of SAR in human tissue in Bangladesh. The SAR values were calculated for the human brain, eye and nerves for both the workers of all Bangladeshi mobile operator and general public. Result showed that among these three tissues, the SAR is lowest for nerves and higher for eyes [22]. Based on Bangladesh perspective an empirical analysis has been done on calculating the safety limit of three human tissues; such as brain, Muscle and skin. And suggested different safety limit on the basis of low power and high-power antenna type [23].

\section{SITUATION IN BANGLADESH}

In a research it is found that, at present Bangladesh is having more than 12 cores cell phone users. 
And for meeting the communication demand it has about 21 thousand and 6 hundred cell phone towers [3]. Another source says about having around 35,000 mobile phone towers in Bangladesh [20]. Among six mobile phone operators, under the naming of Airtel, Banglalink, Citycell, Grameenphone, Robi and TeleTalk, five of them are major carriers in Bangladesh. The Citycell has shut down their services in 2016. It was the oldest and small-scale mobile operator of Bangladesh on the basis of subscribers [4]. Because of excessive demand and to improve the network coverage, the establishment of cell phone towers like green field tower, Roof Top Tower etc. are increasing at populated areas now. As a result of these excessive cell tower set up, the general people have started facing different injurious problems. Like as headache, changes in anxiety, skin rash, mood disorders, fatigue, memory loss, generalized burning sensation, dizziness, episodes of shaking, palpitations, sleeping disturbances, diarrhea, depression, libido disease, irritability, hopelessness, fits, heaviness of chest etc. [3]. An approximate statistics of cell phone towers of different operator in Bangladesh is shown below in Table- I.

The emitted microwaves or high-frequency radio waves from Cell phone towers is harmful towards human health, as microwaves of approximate $1900 \mathrm{MHz}$ frequency is emitted from a mobile phone tower. Recent studies have shown that within one square kilometer, every biological organism is adversely affected by the severe radiation from mobile phone towers [5].

Table- I: Statistics for Bangladeshi Cellular Tower

\begin{tabular}{|c|c|}
\hline Operator name & Number of Cellular Towers \\
\hline Grameenphone & 9500 \\
\hline Banglalink & 5300 \\
\hline Robi & 3056 \\
\hline Airtel & 1700 \\
\hline Teletalk & 594 \\
\hline
\end{tabular}

In general, power density, electric field strength and specific absorption rate there are some indicators to measure radiation. The WHO (world health organization) has mentioned the safety limits of power density and electric field strength at different frequency bands. In Bangladesh the situation is quite alarming. A measurement is carried out by Bangladesh Telecommunication Regulatory Commission on some of radiated power density and electric field strength from all cell phone tower sites in Dhaka city [3]. A comparison between safety limit declared by the WHO and the current situation of Bangladesh is given below in TableII.

Table- II: Comparison between safety limit according to the WHO and present situation in Bangladesh

\begin{tabular}{|c|c|c|c|c|}
\hline Frequency band & $\begin{array}{c}\begin{array}{c}\text { Standard level of power } \\
\text { density (WHO) }\end{array} \\
\end{array}$ & $\begin{array}{c}\text { Power density in } \\
\text { Bangladesh }\end{array}$ & $\begin{array}{c}\text { Standard level of } \\
\text { Electric field (WHO) }\end{array}$ & $\begin{array}{c}\text { Electric field in } \\
\text { Bangladesh }\end{array}$ \\
\hline CDMA 450 & $2.2 \mathrm{~W} / \mathrm{m}^{2}$ & $2.5 \mathrm{~W} / \mathrm{m}^{2}$ & $29 \mathrm{v} / \mathrm{m}$ & $62.56 \mathrm{v} / \mathrm{m}$ \\
\hline GSM 900 & $4.7 \mathrm{~W} / \mathrm{m}^{2}$ & $10.38 \mathrm{~W} / \mathrm{m}^{2}$ & $42 \mathrm{v} / \mathrm{m}$ & $51.05 \mathrm{v} / \mathrm{m}$ \\
\hline GSM 1800 & $9.0 \mathrm{~W} / \mathrm{m}^{2}$ & $10.35 \mathrm{~W} / \mathrm{m}^{2}$ & $58 \mathrm{v} / \mathrm{m}$ & $71.50 \mathrm{v} / \mathrm{m}$ \\
\hline UTMS & $10.01 \mathrm{~W} / \mathrm{m}^{2}$ & $5.5 \mathrm{~W} / \mathrm{m}^{2}$ & $61 \mathrm{v} / \mathrm{m}$ & $65.05 \mathrm{v} / \mathrm{m}$ \\
\hline
\end{tabular}

Additionally, BTRC (Bangladesh telecommunication

Due to the risk of cell phone tower radiation the rent of houses near towers may affect. An experiment has been conducted on Auckland Region, New Zealand, to determine the influence of house prices if the presence of cellular tower. Any significant relationship is not found between cell towers and house prices after this study [9]. In Dhaka, Bangladesh the owners sometimes face difficulties for renting an apartment for the proximity of towers in there roof top. But still lack of awareness exists in many rural residences. The house owners agree to set up rooftop tower on account of healthy yearly amount.

A writ petition was filed in October, 2012, by a rights organization named HRPB (Human Rights and Peace for Bangladesh) for seeking the order from court for preventing mobile-phone tower radiation. On March, 2017 the health ministry submitted an expert committee's report to the HC

(High Court) in relation to the radiation from a carrier's cell tower was found over the limit set by the WHO guidelines. In conformity with WHO, Human health and environmental cycle confronts the challenges by the endless radiation.

In response to the petition submitted in April, 2019, eleven directives has been issued in order to defend people, animal and trees from harmful mobile phone towers radiations. The tribunal specially instructed the authorities to overlook the antenna setup especially when antenna setup at residential building rooftops and to take immediate action to reduce the radiation from mobile phone towers by one percent out of ten percent.
Regulatory Commission) should form a monitoring cell to trace the health issues due to the radiation from the cell tower which is suggested by the tribunal [19].

\section{METHODOLOGY}

For measuring absorbed radiation basically there are 3 indicators; power density, Electric Field Strength, and Specific Absorption Rate. Universally, SAR is used to measure the rate of radiation from the radio frequency which is absorbed by the human body. The standard rate of SAR given by the World Health Organization is $1.66 \mathrm{w} / \mathrm{kg}$. In this empirical analysis we have chosen 9 human tissues for analyzing the impact of radiation effect by calculating the SAR values. Such as blood, tooth, brain, eye (lens), eye (cornea), kidney, muscle, skin and bone. A specific antenna type is taken from HUAWEI, an antenna manufacturing company. The antennae Model: ASI4518R21v06 has been selected for analyzing its effect for 900MHZ, $1800 \mathrm{MHZ}$ and 2100MHZ frequency bands.

This model provides the effective power $1000 \mathrm{w}$ and frequency range 690- 2(2690) MHZ [24].

The equation for calculating SAR is given below [22] 


\section{Effect of Cellular Tower Radiation towards Human Tissues at Bangladesh Context}

$$
\mathrm{SAR}=\frac{\sigma|E|^{2}}{2 \rho}
$$

Here,

\section{$\sigma=$ Tissue conductivity $(S / m)$ \\ $\rho=$ Human mass density $\left(\mathrm{kg} / \mathrm{m}^{2}\right)$ \\ $E=$ Electric field strength $(\mathrm{V} / \mathrm{m})$}

Human mass density represents the amount of mass present in per unit of the body's volume. The standard unit is (kg/m3). Human body produces currents by using electrically active cells within the tissues surrounding those cells. These volume currents make potential difference between electrodes connected to the human body; this is called tissue conductivity.

For calculating Electric field strength, the following equation is used.

$$
E=\frac{\sqrt{\left(10 P_{t} G_{t}\right)}}{R}
$$

Here,

$P_{\mathrm{t}}=$ Transmitted power $(\mathrm{W})$

$G_{\mathrm{t}}=$ Transmission gain $(\mathrm{dB})$

$R=$ Distance $(m)$.

The following Table III represents the density of each tissue and tissue conductivity and relative Permittivity for 900 MHZ, $1800 \mathrm{MHZ}$ and $2100 \mathrm{MHZ}$ frequency bands over 9 types of human tissue. Here relative permittivity is the ratio of the permittivity of a substance to the permittivity of space or vacuum

[25].

\begin{tabular}{|c|c|c|c|c|c|c|c|c|}
\hline \multirow{2}{*}{ NO } & \multirow{2}{*}{ Tissue } & \multirow{2}{*}{$\begin{array}{c}\text { Density } \\
\rho\left[\mathrm{kg} / \mathrm{m}^{3}\right]\end{array}$} & \multicolumn{3}{|c|}{$\begin{array}{c}\text { Conductivity } \\
\sigma[S \backslash \mathrm{m}]\end{array}$} & \multicolumn{3}{|c|}{ Relative Permittivity } \\
\hline & & & $900 \mathrm{MHz}$ & $1800 \mathrm{MHz}$ & $2100 \mathrm{MHz}$ & $900 \mathrm{MHz}$ & $1800 \mathrm{MHz}$ & $2100 \mathrm{MHz}$ \\
\hline 1 & Blood & 1060 & 1.54 & 2.00 & 2.20 & 61.4 & 59.3 & 58.8 \\
\hline 2 & Tooth & 1040 & 0.14 & 0.27 & 0.30 & 12.5 & 11.7 & 11.6 \\
\hline 3 & Brain & 1030 & 1.26 & 1.70 & 1.80 & 49.4 & 46.1 & 45.4 \\
\hline 4 & Eye(Lens) & 1050 & 0.48 & 0.78 & 0.91 & 35.8 & 34.6 & 34.3 \\
\hline 5 & Eye(kornea) & 1050 & 1.39 & 1.80 & 2.00 & 55.2 & 52.7 & 52.2 \\
\hline 6 & Kidney & 1030 & 1.39 & 1.94 & 2.10 & 58.6 & 54.4 & 53.5 \\
\hline 7 & Muscle & 1040 & 0.94 & 1.34 & 1.50 & 55.0 & 53.54 & 53.1 \\
\hline 8 & Skin & 1100 & 0.86 & 1.18 & 1.30 & 41.4 & 38.8 & 38.4 \\
\hline 9 & Bone & 1850 & 0.14 & 0.27 & 0.30 & 12.4 & 11.7 & 11.5 \\
\hline
\end{tabular}

Table III: Physical and electrical parameter of human tissue

\section{RESULT AND DISCUSSION}

For calculating SAR for multiple human tissues at several distances regards to our chosen antenna we need the value of $\mathrm{E}$, the induced electric field strength. $\mathrm{E}$ is a quantitative expression of the intensity of an electric field at a particular location. The safety limit of electric field strength mentioned by the WHO and the scenario of Bangladesh are mentioned in Table II. For the calculation of SAR, we have been chosen HUAWEI cellular antenna Model: ASI4518R21v06 which provides frequency range $(690-862) \mathrm{MHz}-2 \times(1695-2690)$ $\mathrm{MHz}$ As we are dealing with $900 \mathrm{MHZ}, 1800 \mathrm{MHZ}$ and 2100 MHZ frequency bands of a specific chosen antenna, the effective power by the antenna $\left(P_{t}\right)$ in different frequency band will remain the same, that is $1000 \mathrm{~W}$. And the transmission gain of the antenna $\left(G_{t}\right)$ is different for different frequency band. $16 \mathrm{db}$ for $900 \mathrm{MHZ}$ frequency, $17 \mathrm{db}$ for $1800 \mathrm{MHZ}$ frequency and $17.5 \mathrm{db}$ for $2100 \mathrm{MHZ}$ frequency. The result of SAR calculation for these three frequency bands are represented in Table IV, Table V and Table VI sequentially

Table- IV: SAR Calculation for 900 MHZ frequency band for HUAWEI cellular antenna Model: ASI4518R21v06

\begin{tabular}{|l|c|c|c|c|c|c|c|c|c|c|c|c|}
\hline Human Tissue & $\mathbf{1 m}$ & $\mathbf{2 m}$ & $\mathbf{3 m}$ & $\mathbf{3 . 5 m}$ & $\mathbf{4 m}$ & $\mathbf{6 m}$ & $\mathbf{8 m}$ & $\mathbf{1 0 m}$ & $\mathbf{1 5 m}$ & $\mathbf{1 8 m}$ & $\mathbf{2 0 m}$ & $\mathbf{3 0 m}$ \\
\hline Blood & 348.68 & 87.17 & 38.74 & 28.46 & 21.79 & 9.69 & 5.45 & 3.49 & 1.55 & 1.08 & 0.87 & 0.39 \\
\hline Tooth & 32.31 & 8.08 & 3.59 & 2.64 & 2.02 & 0.90 & 0.50 & 0.32 & 0.14 & 0.10 & 0.08 & 0.04 \\
\hline Brain & 293.59 & 73.40 & 32.62 & 23.97 & 18.35 & 8.16 & 4.59 & 2.94 & 1.30 & 0.91 & 0.73 & 0.33 \\
\hline Eye(Lens) & 109.71 & 27.43 & 12.19 & 8.96 & 6.86 & 3.05 & 1.71 & 1.10 & 0.49 & 0.34 & 0.27 & 0.12 \\
\hline Eye(kornea) & 317.71 & 79.43 & 35.30 & 25.94 & 19.86 & 8.83 & 4.96 & 3.18 & 1.41 & 0.98 & 0.79 & 0.35 \\
\hline Kidney & 323.88 & 80.97 & 35.99 & 26.44 & 20.24 & 9.00 & 5.06 & 3.24 & 1.44 & 1.00 & 0.81 & 0.36 \\
\hline Muscle & 216.92 & 54.23 & 24.10 & 17.71 & 13.56 & 6.03 & 3.39 & 2.17 & 0.96 & 0.67 & 0.54 & 0.24 \\
\hline Skin & 187.64 & 46.91 & 20.85 & 15.32 & 11.73 & 5.21 & 2.93 & 1.88 & 0.83 & 0.58 & 0.47 & 0.21 \\
\hline Bone & 18.16 & 4.54 & 2.02 & 1.48 & 1.14 & 0.50 & 0.28 & 0.18 & 0.08 & 0.06 & 0.05 & 0.02 \\
\hline
\end{tabular}


Table- V: SAR Calculation for $1800 \mathrm{MHZ}$ frequency band for HUAWEI cellular antenna Model: ASI4518R21v06

\begin{tabular}{|c|c|c|c|c|c|c|c|c|c|c|c|c|}
\hline Human Tissue & $1 \mathrm{~m}$ & $2 \mathrm{~m}$ & $3 \mathbf{m}$ & $3.5 \mathrm{~m}$ & $4 m$ & $6 \mathrm{~m}$ & $8 \mathrm{~m}$ & $10 \mathrm{~m}$ & $15 \mathrm{~m}$ & $18 \mathrm{~m}$ & $20 \mathrm{~m}$ & $30 \mathrm{~m}$ \\
\hline Blood & 481.13 & 120.28 & 53.46 & 39.28 & 30.07 & 13.36 & 7.52 & 4.81 & 2.14 & 1.63 & 1.20 & 0.53 \\
\hline Tooth & 66.20 & 16.55 & 7.36 & 5.40 & 4.14 & 1.84 & 1.03 & 0.66 & 0.29 & 0.23 & 0.17 & 0.07 \\
\hline Brain & 420.87 & 105.22 & 46.76 & 34.36 & 26.30 & 11.69 & 6.58 & 4.21 & 1.87 & 1.38 & 1.05 & 0.47 \\
\hline Eye(Lens) & 189.43 & 47.36 & 21.05 & 15.46 & 11.84 & 5.26 & 2.96 & 1.89 & 0.84 & 0.68 & 0.47 & 0.21 \\
\hline Eye(kornea) & 437.14 & 109.29 & 48.57 & 35.69 & 27.32 & 12.14 & 6.83 & 4.37 & 1.94 & 1.50 & 1.09 & 0.49 \\
\hline Kidney & 480.29 & 120.07 & 53.37 & 39.21 & 30.02 & 13.34 & 7.50 & 4.80 & 2.13 & 1.60 & 1.20 & 0.53 \\
\hline Muscle & 328.56 & 82.14 & 36.51 & 26.82 & 20.53 & 9.13 & 5.13 & 3.29 & 1.46 & 1.14 & 0.82 & 0.37 \\
\hline Skin & 273.55 & 68.39 & 30.39 & 22.33 & 17.10 & 7.60 & 4.27 & 2.74 & 1.22 & 0.93 & 0.68 & 0.30 \\
\hline Bone & 37.22 & 9.30 & 4.14 & 3.04 & 2.33 & 1.03 & 0.58 & 0.37 & 0.17 & 0.13 & 0.09 & 0.04 \\
\hline
\end{tabular}

Table VI: SAR Calculation for 2100 MHZ frequency band for HUAWEI cellular antenna Model: ASI4518R21v06

\begin{tabular}{|c|c|c|c|c|c|c|c|c|c|c|c|c|}
\hline Human Tissue & $1 \mathrm{~m}$ & $2 \mathrm{~m}$ & $3 m$ & $3.5 \mathrm{~m}$ & $4 m$ & $6 \mathrm{~m}$ & $8 m$ & $10 \mathrm{~m}$ & $15 \mathrm{~m}$ & $18 m$ & $20 m$ & $30 \mathrm{~m}$ \\
\hline Blood & 544.81 & 136.20 & 60.53 & 44.47 & 34.05 & 15.13 & 8.51 & 5.45 & 2.42 & 1.68 & 1.36 & 0.61 \\
\hline Tooth & 75.72 & 18.93 & 8.41 & 6.18 & 4.73 & 2.10 & 1.18 & 0.76 & 0.34 & 0.23 & 0.19 & 0.08 \\
\hline Brain & 458.74 & 114.68 & 50.97 & 37.45 & 28.67 & 12.74 & 7.17 & 4.59 & 2.04 & 1.42 & 1.15 & 0.51 \\
\hline Eye(Lens) & 227.50 & 56.88 & 25.28 & 18.57 & 14.22 & 6.32 & 3.55 & 2.28 & 1.01 & 0.70 & 0.57 & 0.25 \\
\hline Eye(kornea) & 500.00 & 125.00 & 55.56 & 40.82 & 31.25 & 13.89 & 7.81 & 5.00 & 2.22 & 1.54 & 1.25 & 0.56 \\
\hline Kidney & 535.19 & 133.80 & 59.47 & 43.69 & 33.45 & 14.87 & 8.36 & 5.35 & 2.38 & 1.65 & 1.34 & 0.59 \\
\hline Muscle & 378.61 & 94.65 & 42.07 & 30.91 & 23.66 & 10.52 & 5.92 & 3.79 & 1.68 & 1.17 & 0.95 & 0.42 \\
\hline Skin & 310.23 & 77.56 & 34.47 & 25.32 & 19.39 & 8.62 & 4.85 & 3.10 & 1.38 & 0.96 & 0.78 & 0.34 \\
\hline Bone & 42.57 & 10.64 & 4.73 & 3.47 & 2.66 & 1.18 & 0.67 & 0.43 & 0.19 & 0.13 & 0.11 & 0.05 \\
\hline
\end{tabular}

From the above calculation have calculated the SAR with consider to distance from the base station. According to
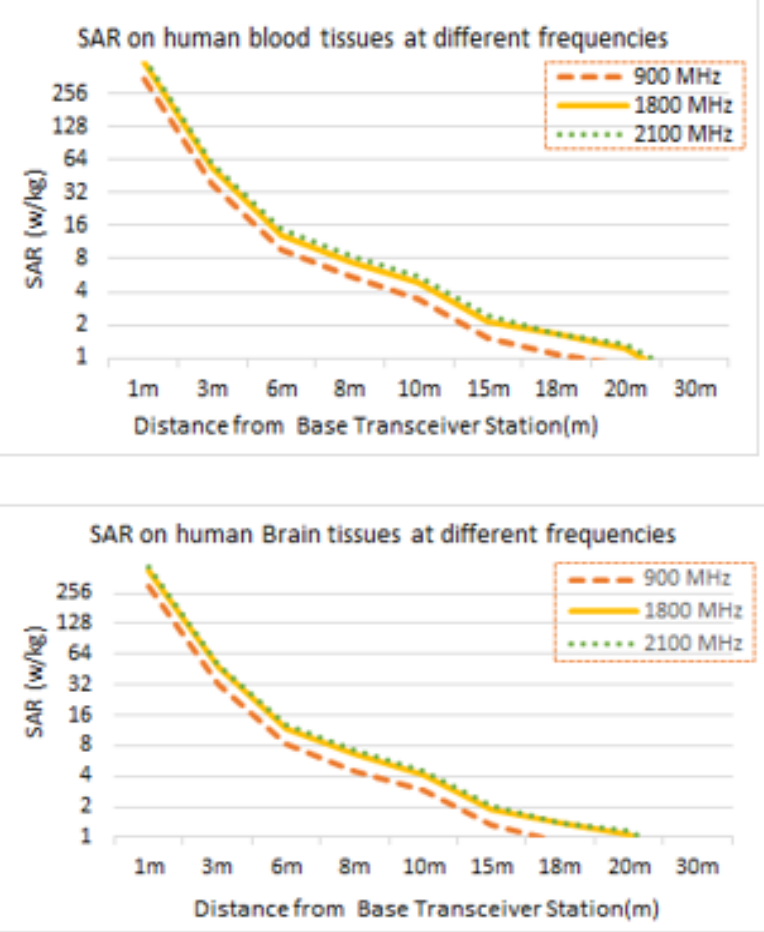

WHO, SAR is $1.66(\mathrm{w} / \mathrm{kg})$ so that the safety limit for each of 9 tissues have been shown in the below figure separately.

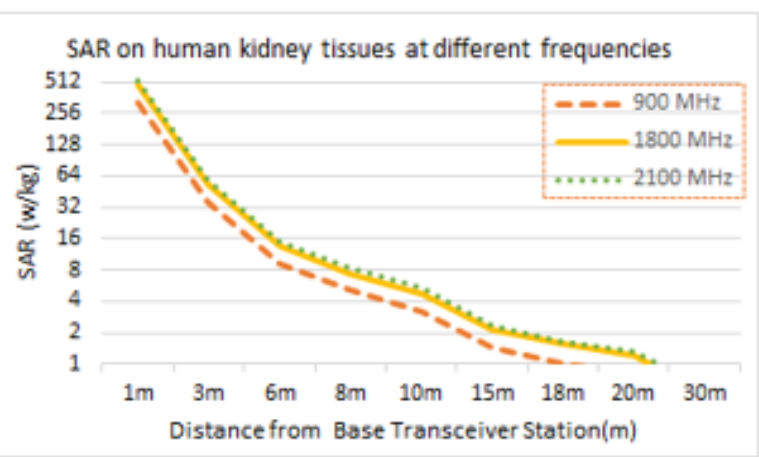

SAR on human Muscle tissues at different frequencies

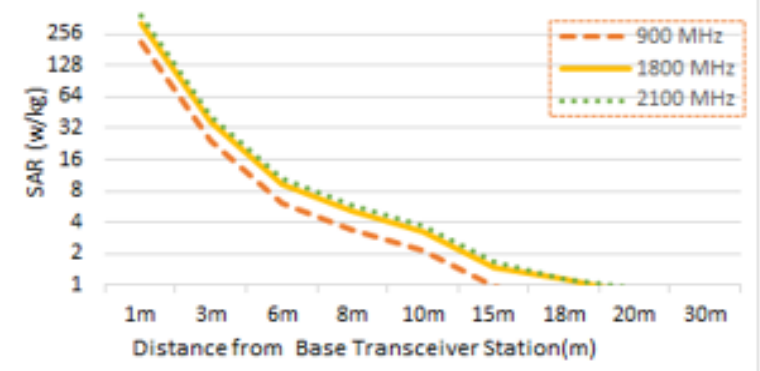

Fig. 1. SAR on human blood, kidney, brain \& muscle tissues in several distances and frequencies

In Fig 1 represents the SAR value on human blood, kidney, brain \& muscle tissues in different distances with the frequency $900 \mathrm{MHz}, 1800 \mathrm{MHz}$ and $2100 \mathrm{MHz}$. It can be observed that SAR value greater than the safety limit till $15 \mathrm{~m}$
$-18 \mathrm{~m}$ for blood tissues, $14 \mathrm{~m}-18 \mathrm{~m}$ for kidney tissues, $14 \mathrm{~m}-17 \mathrm{~m}$ for brain \& $12 \mathrm{~m}-16 \mathrm{~m}$ for muscle.
Retrieval Number: C5941029320/2020@BEIESP DOI: 10.35940/ijeat.C5941.029320 Journal Website: www.ijeat.org 


\section{Effect of Cellular Tower Radiation towards Human Tissues at Bangladesh Context}
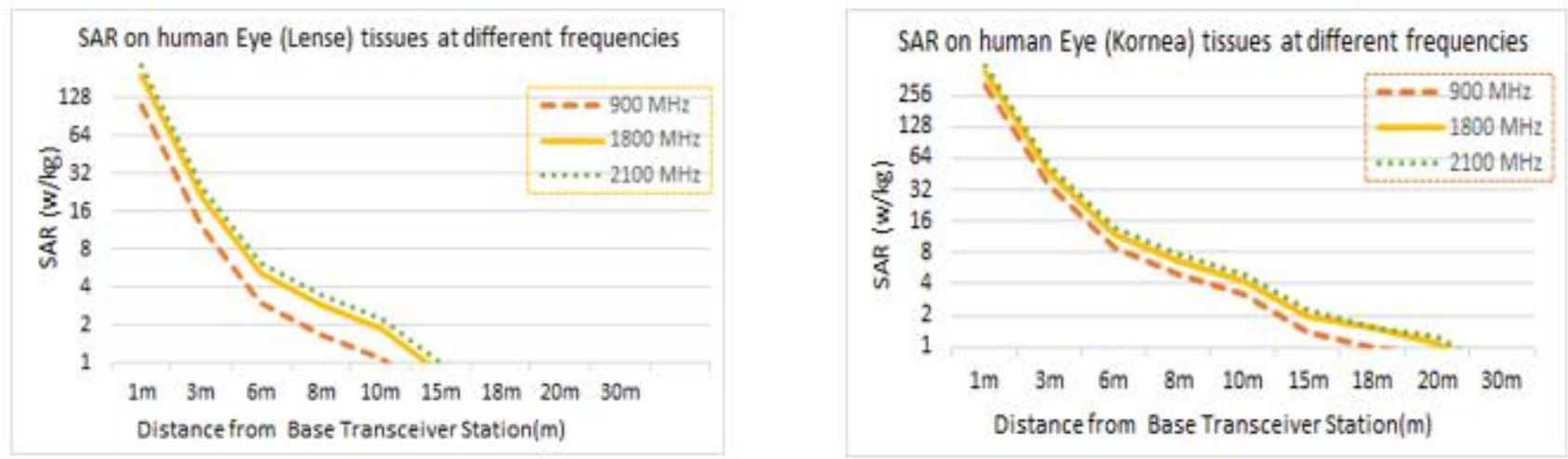

Fig. 2. SAR on human eye (lens) \& Eye (cornea) tissues in several distances and frequencies

In fig 2 states that the SAR value of human eye (lens) is greater than the safety limits up to $9 \mathrm{~m}-12 \mathrm{~m}$ and for eye (cornea) safe distance is $14 \mathrm{~m}-18 \mathrm{~m}$ from the base station.

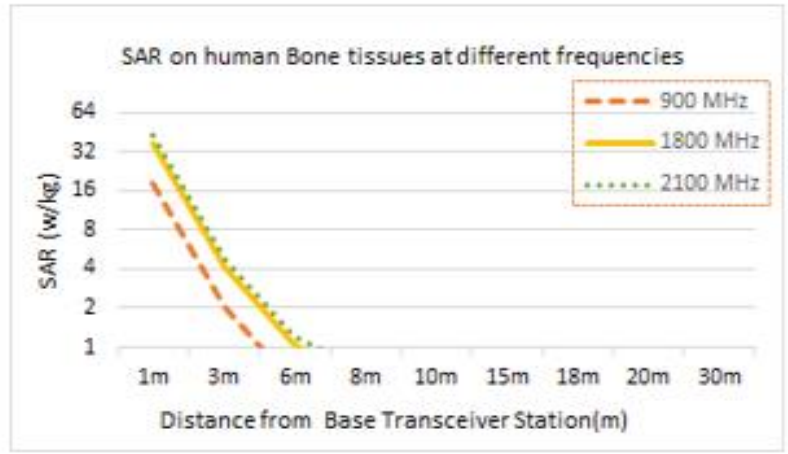

From the experimental calculation it is obtained that the eye (lens) is being affected within the smaller distance from the base station compare to eye (cornea).

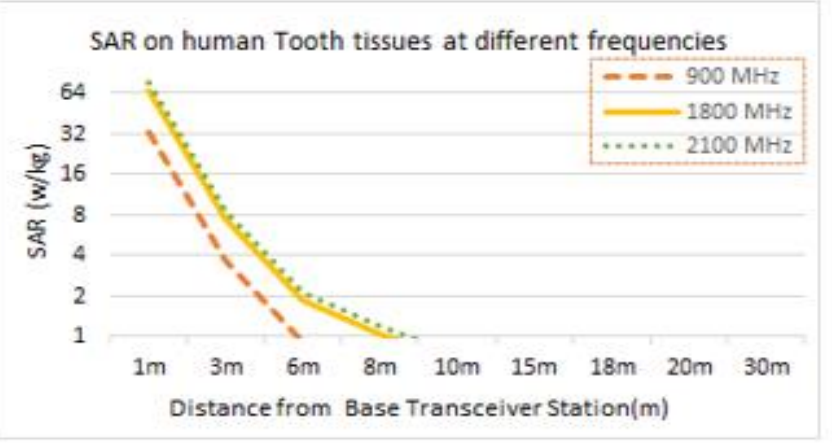

Fig. 3. SAR on human bone \& tooth tissues in several distances and frequencies

In Fig 3, represents that the SAR value and distance at different frequencies. The bearable SAR value starts from $4 \mathrm{~m}$ for bone tissue and $5 \mathrm{~m}$ for tooth tissue.

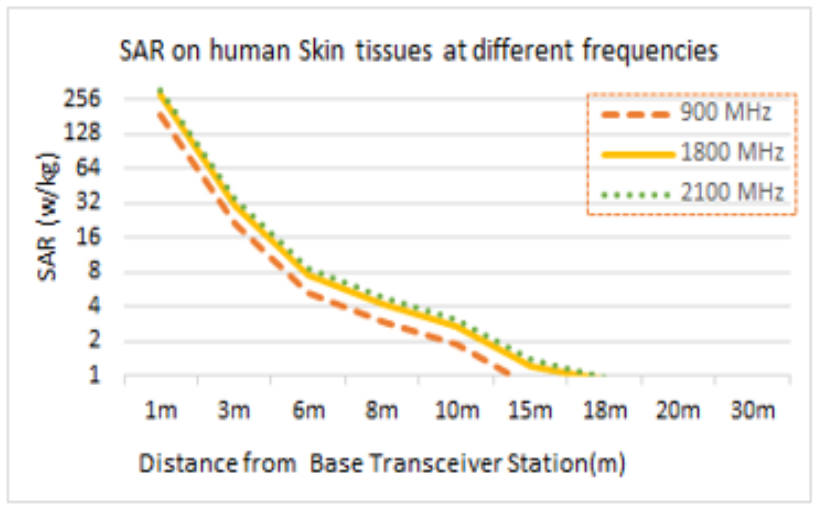

\section{Fig. 4. SAR on human skin tissues in several distances and frequencies}

In Fig 4, it is found that the safety limit starts from $11 \mathrm{~m}$ and it's varied up to $14 \mathrm{~m}$ based on allowed frequency band in Bangladesh.

From the above analysis, we have found that the blood tissue is required more distance antenna set up and bone tissue is required less distance from the base station. Finally, this research suggests that in the base station set up distance should be $15 \mathrm{~m}$ away from the overcrowded area.

\section{CONCLUSION}

In this research the radiation disclosure study from the base station towards human body tissues are done in devoted fashion. These tissues are blood, teeth, brain, eye (lens), eye (cornea), kidney, muscle, skin and bone. And also shows the statistics with respect to cellular tower, power density and electric field at Bangladesh context. One particular model of base station antenna is used for SAR calculation with effective power and different gain with the frequency $900 \mathrm{MHz}, 1800 \mathrm{MHz} \& 2100 \mathrm{MHz}$ which are likely used frequency bands in Bangladesh.

As in Bangladesh, the establishment of cellular base station is increasing in residential areas mostly in roof top, nearest educational institute, market and habitation etc. without any concern of human health issues. So, Cellular tower should be placed by maintaining secure distance from densely populated areas. In view of our research it can be stated that, in order to save the mentioned above 9 human tissues the cellular base station should be set up from at least $15 \mathrm{~m}$ away from the local area.

\section{ACKNOWLEDGMENT}

Authors' would like to show gratitude to the Department of Computer Science and Engineering at Daffodil International University, Dhaka, Bangladesh for continuous support to complete this research work. 


\section{REFERENCES}

1. K. Vishnu, B. Nithyaja, C. Pradeep, R. Sujith, P. Mohanan, and V. Nampoori, "Studies on the effect of mobile phone radiation on DNA using laser induced fluorescence technique," Laser Physics, vol. 21, no. 11, pp. 1945-1949, 2011W.-K. Chen, Linear Networks and Systems (Book style). Belmont, CA: Wadsworth, 1993, pp. 123-135.

2. A. López-Furelos, J. M. Leiro-Vidal, A. Á. Salas-Sánchez, F. J. Ares-Pena, and M. E. López-Martín, "Evidence of cellular stress and caspase-3 resulting from a combined two-frequency signal in the cerebrum and cerebellum of sprague-dawley rats," Oncotarget, vol. 7, no. 40, p. 64674, 2016.

3. S. Reza, "Environmental and Public Health Risks of Cell Phone Towers Radiation in Bangladesh", http://dhakacourier.com.bd/, 2019. [Online].Available:http://www.dhakacourier.com.bd/news/Reportage/ Environmental-and-Public-Health-Risks-of-Cell-Phone-Towers-Radia tion-in-Bangladesh/1056. [Last Accessed: 23- Nov- 2019].

4. "Citycell", En.wikipedia.org. [Online]. Available: https://en.wikipedia.org/wiki/Citycell. [Last Accessed: 24- Nov2019].

5. "EMF Health Effects", Safe Space Protection. [Online]. Available: https://www.safespaceprotection.com/emf-health-risks/emf-health-eff ects/cell-towers/. [Last Accessed: 20- Nov- 2019].

6. World Health Organization, ELF Health Criteria Monograph. Neurodegenerative Disorders, p187, 2007.

7. Hocking, B., et al, "Cancer incidence and mortality and proximity to TV towers, Medical Journal of Australia", 165, 601-605, 1996.

8. Abdel-Rassoul G, et al, "Neurobehavioral effects among inhabitants around mobile phone base stations", Neurotoxicology, 28(2), 434-40, 2006.

9. Filippova, Olga, and Michael Rehm. "The impact of proximity to cell phone towers on residential property values." International Journal of Housing Markets and Analysis 4, no. 3 (2011): 244-267.

10. Sivani, S., and D. Sudarsanam. "Impacts of radio-frequency electromagnetic field (RF-EMF) from cell phone towers and wireless devices on biosystem and ecosystem-a review." Biology and Medicine 4, no. 4 (2012): 202.

11. Expert Group to study the possible impacts of communication towers on Wildlife including Birds and Bees.

12. [Online]. Available: http://www.thenhf.com/article.php?id5480. [Last Accessed: 30- Jan- 2020].

13. Lai, Henry. "Single-and double-strand DNA breaks in rat brain cells after acute exposure to radiofrequency electromagnetic radiation." International journal of radiation biology 69, no. 4 (1996): 513-521.

14. Kane, Robert C. Cellular telephone Russian roulette: a historical and scientific perspective. Vantage Press, 2001.

15. Wolf, Ronni, and Danny Wolf. "Increased incidence of cancer near a cell-phone transmitter station." International Journal of Cancer 1, no. 2 (2004): 123-128.

16. Moszczyński, P., J. Lisiewicz, A. Dmoch, Z. Zabiński, L. Bergier, M. Rucińska, and U. Sasiadek. "The effect of various occupational exposures to microwave radiation on the concentrations of immunoglobulins and $\mathrm{T}$

17. Kumar, Neha, and Girish Kumar. "Biological effects of cell tower radiation on human body." ISMOT, Delhi, India (2009): 678-679.

18. Leszczynski, Dariusz, Sakari Joenväärä, Jukka Reivinen, and Reetta Kuokka. "Non-thermal activation of the hsp27/p38MAPK stress pathway by mobile phone radiation in human endothelial cells: molecular mechanism for cancer-and blood-brain barrier-related effects." Differentiation 70, no. 2-3 (2002): 120-129.

19. "HC asks BTRC for report on mobile tower radiation", Dhaka Tribune, 2019. [Online]. Available: https://www.dhakatribune.com/bangladesh/court/2019/04/25/hc-asksbtrc-for-report-on-mobile-tower-radiation. [Last Accessed: 20- Oct2019].

20. "HC seeks BTRC report on mobile tower radiation", The Daily Star, 2019.

[Online].

Available: https://www.thedailystar.net/business/telecom/cell-phone-tower-radiat ion-effects-hc-seeks-btrc-report-1734604. [Last Accessed: 21- Oct2019].

21. "A Culture of Smartphone Dependence", Southuniversity.edu, 2017. [Online].

Available: https://www.southuniversity.edu/news-and-blogs/2017/08/a-culture-o f-smartphone-obsession. [Last Accessed: 01- Jan- 2020].

22. Hoque, A. K. M. F., Md Sazzad Hossain, A. Sattar Mollah, and Md Akramuzzaman. "A study on specific absorption rate (SAR) due to nonionizing radiation from wireless/telecommunication in Bangladesh." Am. J. Phys. Appl 1, no. 3 (2013): 104-110.

23. Faisal, Muhammad Mostafa Amir, Mohammad Golam Mortuza, and Towhidul Alam. "Cell Tower Radiation and Effect on Human Body:
Bangladesh Perspective." In 2018 International Conference on Innovations in Science, Engineering and Technology (ICISET), pp. 423-426. IEEE, 2018.

24. huawei.

[Online].

Available: https://carrier.huawei.com/en/products-wireless-network/Antenna/ant enna-list/antenna- search?Keywords=\%20ASI4518R21v06. [Last Accessed: 18- Dec- 2019].

25. Engineering ToolBox, (2010). Relative Permittivity - the Dielectric Constant. [online] Available at: https://www.engineeringtoolbox.com/relative-permittivity-d_1660.ht ml [Last Accessed: 15- Oct- 2019].

\section{AUTHORS PROFILE}

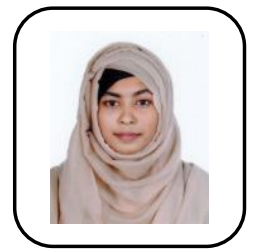

Tapasy Rabeya currently serving as a Lecturer in Computer Science and Engineering department at Daffodil International University, Bangladesh. She has completed her graduation from Daffodil International University. Now she is pursuing her post-graduation in Daffodil International University. With 2 years teaching experience, she has 3 publications in international conferences. Her research interest covers Data mining, NLP, Sentiment Analysis and Blockchain Technology.

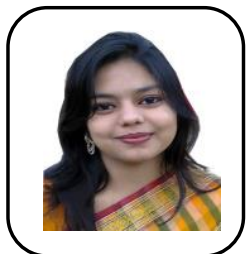

Mst. Eshita Khatun currently working as Lecturer in the Department of Computer Science and Engineering at Daffodil International University, Bangladesh. She obtained B.Sc. in CSE from the Daffodil International University. Now she is studying M.Sc. in Daffodil International University. She has 2.5 years of teaching experience. Her research working area is IoT, Big Data and

Blockchain Technology.

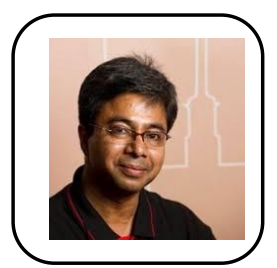

Syed Akhter Hossain is currently working as professor and Head of the Department of Computer Science and Engineering at Daffodil International University, Bangladesh. Dr. Hossain obtained M.Sc. in Applied Physics and Electronics from Rajshahi University and Ph.D. in Computer Science and Engineering from university of Dhaka. He attended Erasmus Mundus post-doctoral fellowship in the area of Informatics and Industria Engineering with University Lumiere Lyon 2 in France. He has more than 25 years of working experience in industry, education, research and training. He is actively involved in research guidance/ research projects/ research collaborations with Institutes/ Industries and has more than 75 publications/ presentations and his work is listed in DBLP, IEEE Explore and other research databases. He received National ICT Award 2016 for his outstanding contribution in ICT education. He also received other International awards for teaching including other national awards for his scholastic works especially for the contribution of machine translator for Bangla Braille used by the visually impaired society. He is also member of several national and international professional bodies. 